DOI: http://dx.doi.org/10.1590/01047760.201420021358

\title{
CHARACTERIZATION OF Pinus spp NEEDLES AND EVALUATION OF THEIR POTENTIAL USE FOR ENERGY
}

\author{
Graciela Inés Bolzon de Muñiz ${ }^{1}$, Elaine Cristina Lengowski ${ }^{1}$, Silvana Nisgoski ${ }^{1 *}$, Washington Luis Esteves de \\ Magalhães $^{2}$, Valcineide Tanobe de Oliveira ${ }^{1}$, Fabrício Hansel ${ }^{2}$
}

*Autor para correspondência: nisgoski@ufpr.br

\begin{abstract}
The demand for new energy sources is growing and awakening interest in the use of forest residues. Charcoal was prepared at carbonization temperatures of $500{ }^{\circ} \mathrm{C}, 600^{\circ} \mathrm{C}$ and $700{ }^{\circ} \mathrm{C}$ in order to evaluate the potential use of Pinus sp needles for energy. The anatomical and chemical characteristics of the needles and the charcoal produced were also evaluated. The needles were found to have ash content of $2.32 \%$ and gross calorific value of $20.30 \mathrm{MJ} / \mathrm{kg}$. The calorific value increased by $45 \%$, reaching $29.64 \mathrm{MJ} / \mathrm{kg}$, after carbonization carried out at $600^{\circ} \mathrm{C}$. This value is higher than that for charcoal made from eucalyptus (19.25 MJ/ $\mathrm{kg}$ ) and even coconut husks (23.55 MJ/kg), showing the high energy potential of these needles.
\end{abstract}

Keywords: charcoal, pine, forest residue.

\section{CARACTERIZAÇÃo E AVALIAÇÃo do PONTENCIAL DE USO DE ACÍCULAS DE Pinus sp. PARA ENERGIA}

RESUMO: A crescente demanda por novas fontes de energia vem aumentando o interesse em pesquisas para a utilização de resíduos florestais. Foram preparados carvões a temperaturas de $500{ }^{\circ} \mathrm{C}, 600{ }^{\circ} \mathrm{C}$ e $700{ }^{\circ} \mathrm{C}$ com o objetivo de avaliar o potencial de uso de acículas de Pinus spp. para energia. Foram avaliadas as características anatômicas e químicas das acículas e do carvão produzido. O conteúdo de cinzas das acículas foi de $2,32 \%$ e o poder calorífico de $20,30 \mathrm{MJ} / \mathrm{kg}$. O poder calorífico aumentou $45 \%$, alcançando $29,64 \mathrm{MJ} / \mathrm{kg}$ após a carbonização em temperatura de $600^{\circ} \mathrm{C}$. Esse valor é superior ao carvão feito de eucalipto $(19,25 \mathrm{MJ} / \mathrm{kg})$ e coco $(23,55 \mathrm{MJ} / \mathrm{kg})$, mostrando o bom potencial de uso para energia.

Palavras-chave: carvão, pinus, resíduos florestais.

\section{INTRODUCTION}

The development of mankind is closely associated with the increase in energy consumption and the rational and controlled use of different energy sources. The oil crisis in the 1970s led to new concepts of economic, environmental and social sustainability, encouraging the generation and consumption of energy from renewable and less polluting sources (SOARES et al., 2006).

In Brazil, the generation and production of agroforestry biomass energy is one of the main alternatives to replace oil and its derivatives, designed to meet the demands of the urban residential, rural and industrial sectors, especially steelmaking. In assessing the availability of biomass for energy purposes in a region, it is important to consider the ecological, economic, social, political and technological constraints, all of which are associated with environmental preservation and life quality. There are different technologies for biomass processing and transformation into energy. Some present problems of high

1 Universidade Federal do Paraná - Curitiba, Paraná, Brasil

2 Embrapa Florestas - Colombo, Paraná, Brasil cost and low efficiency in energy production (CORTEZ et al., 2008).

Forest biomass can be a source of clean, renewable energy. Its use can balance the needs of the rural environment and urban development, while generating jobs through specific technology, either by direct burning of wood or by the production of charcoal. Special consideration should go to the use of forestry waste and carbonization byproducts such as tar, pyroligneous acid and other derivatives in the chemical and automotive industries (CORTEZ et al., 2008).

The materials commonly used as biomass have calorific values ranging from 2.39 to $23.88 \mathrm{MJ} / \mathrm{kg}$, such as sawdust (5.97 MJ / kg), wood chips (5.97 MJ / kg), wood tar (14.14 MJ / kg), wood bark (2.39 MJ / kg), charcoal (16.24 MJ / kg), bagasse (5.37 MJ / kg), soybean hulls (5.97 MJ / kg), castor oil cake (10.75 MJ / kg), rubber dust (19.11 MJ / kg), black liquor (2.15 MJ / kg) (REDENERGIA, 2010), pine needles (11.96 MJ / kg) and pine bark (11.76 MJ / kg) (THÖRNQVIST, 1985).

Cerne, Lavras, v. 20, n. 2, p. 245-250, abr./jun. 2014 
Pine needles are a still unexploited forest residue. An estimate made by Couto and Brito (1980) showed that eight-year-old Pinus oocarpa trees produce an average of $17.4 \mathrm{~kg}$ of needles / tree at $50 \%$ moisture. In most growing areas, the needles basically serve as ground cover and can facilitate the spread of fires or even shelter vermin. For these reasons, they are eliminated in many cases by chemical, biological and/or mechanical means. In order to reduce the combustible material inside planted forests, controlled burning is used, which although dangerous, has low cost. However, this forgoes the potential value of the biomass produced and contributes to global warming by emission of $\mathrm{CO}_{2}, \mathrm{NO}_{2}$ and particulates into the atmosphere.

Most studies with needles focus on the anatomical structures, which depend on the species and have particular characteristics that range from their shape to the arrangement and number of constituents. The anatomical elements of needles of Pinus sp. are the mesophyll, hypodermis, epidermis, stomata, endodermis, phloem, xylem, canals, and resin and transfusion tissues (MANCILLA; TOMAZELLO, 1984).

The objective of this study was to evaluate the potential use of pine needles as an energy source, through anatomical and chemical characterization of the material, to provide a basis for future applications.

\section{MATERIAL AND METHODS}

Random samples of needles were collected in order to make histological slides and to identify the species. The anatomical characterization of the material followed the procedure described by Johansen (1940).

The needles were ground in a Wiley mill and then were classified for the carbonization and chemical analysis in accordance with the TAPPI standards (TECHNICAL ASSOCIATION OF PULP AND PAPER INDUSTRY TAPPI, 1994).

The true density of the obtained coal was determined using the pycknometer method by the diffusion of helium gas through the porous structure of the investigated samples in a Quantachrome multi-pycknometer (Model: Ultrapycknometer 1000).

The carbonization of the material described above was performed in a muffle furnace, fitted with a ramp controller at the Embrapa Forest Research Station. The heating rate was $10^{\circ} \mathrm{C} \mathrm{min}-1$ until final temperatures of 500 ${ }^{\circ} \mathrm{C}, 600^{\circ} \mathrm{C}$ and $700{ }^{\circ} \mathrm{C}$, each of which was maintained for 2 $\mathrm{h}$, after which the samples were cooled naturally overnight.
Fresh needles and material extracted in ethanol, toluene and hot water before carbonization were only used for the temperature of $500{ }^{\circ} \mathrm{C}$. Around $0.25 \mathrm{~g}$ of milled sample was added to 10 microliters of cholestane $(10 \mathrm{mg} / \mathrm{ml})$. The samples were extracted with $10 \mathrm{~mL}$ of a solvent mixture of chloroform: acetone (9:1) (3x15 min, ultrasound). The extract was dried under nitrogen stream and transferred to a test tube for esterification (methanol: acetyl chloride (9:1), $2 \mathrm{~mL}, 12 \mathrm{~h}, 65^{\circ} \mathrm{C}$ ) and after purification was silanized (BSTFA, $30 \mu 1,1 \mathrm{~h}, 70^{\circ} \mathrm{C}$ ). After drying with $\mathrm{N}_{2}$ gas, the extract was fattened with $0.5 \mathrm{ml}$ of hexane and analyzed by gas chromatography (GC $-\mathrm{MS})$.

The volatile content, fixed carbon and ash, on a dry basis of the charred needles, were determined according to the ABNT NBR 8112 standard (ASSOCIAÇÃO BRASILEIRA DE NORMAS TÉCNICAS - ABNT, 1984). The calorific value of the material was determined using an IKA model 5000 calorimeter, according to ABNT NBR 8633 (ABNT, 1983).

For illustration, images were obtained by optical microscopy (OM) with an Olympus C40 microscope and by scanning electron microscopy (SEM) in a JEOL JSM6360LV, using accelerating voltage of the electron beam of $15 \mathrm{KV}$, at Parana Federal University.

\section{RESULTS AND DISCUSSION}

Evaluation of histological sections of the needles enabled identifying the species Pinus taeda (Figure 1A, C), with triangular-shaped needles having an average of two resin channels, and Pinus elliottii (Figure 1B, D), with oval shaped needles having an average of four resin channels. Figure 1C shows the formation of a resin ball on the surface of the cross section of Pinus taeda. Both species have the following characteristics:

- A row of sclerenchyma involving the resin channels (Figure 1 A, B);

- Intrusion slightly pronounced toward the hypodermis and mesophyll, with an average of two homogeneous layers of uniform cells (Figure 1 A, B);

- Endoderm cells or a single homogeneous form (Figure 1 A, B);

- Stomata present on every surface along with a beak-like feature (Figure 1 A-D);

- In the dermal regions, two layers of cells from the hypodermis, on average (Figure 1 A, B);

- In the fibrovascular region, two fibrovascular bundles (Figure $1 \mathrm{~A}, \mathrm{~B}$ ); and 
- Sclerenchyma near the phloem (Figure 1 A, B).

On the longitudinal surface, Pinus taeda (Figure

E) and Pinus elliottii (Figure F) have a porous structure resulting from the conformation of the elements listed above. The resin channels are arranged horizontally for both species in these images.

The observed characteristics are consistent with previous studies of Garcia-Alvarez et al. (2009) and Mancilla and Tomazello (1984) on different species of Pinus.
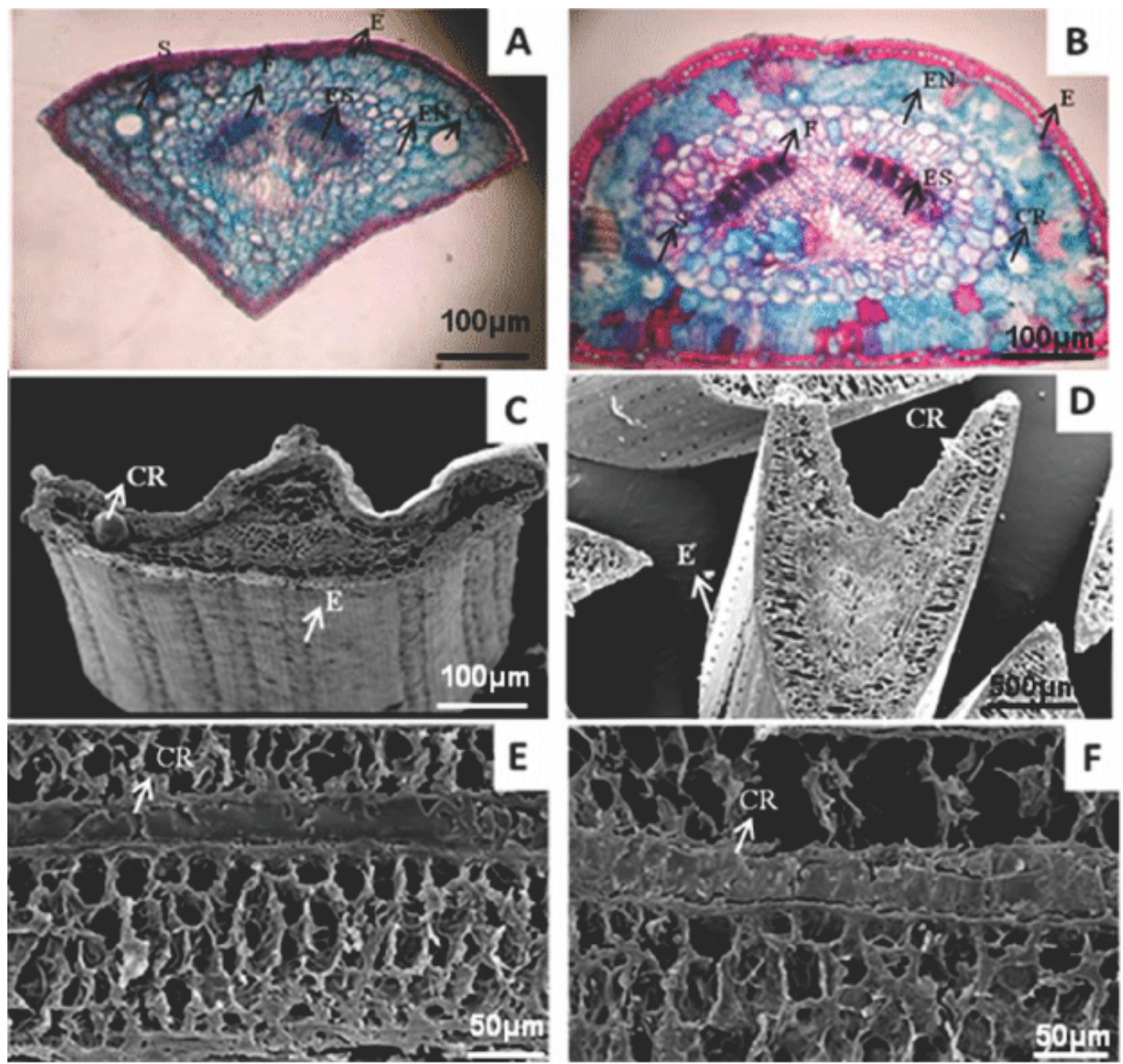

Figure 1 - Optical micrographs of Pinus taeda (A) and Pinus elliottii (B) needles; SEM transversal view of Pinus taeda (C) and Pinus elliottii (D) needles; SEM longitudinal view of Pinus taeda (E) and Pinus elliottii (F) needles; sclerenchyma (S, ES); phloem (F); endoderm cell (EN); stomata (E); resin canal (CR).

Figura 1 - Microscopia óptica das acículas de Pinus taeda (A) e Pinus elliottii (B); MEV do plano transversal das acículas de Pinus taeda (C) e Pinus elliottii (D); MEV do plano longitudinal das acículas de Pinus taeda (E) e Pinus elliottii (F); esclerênquima (S, ES); floema (F); células de endoderme (EN), estômato (E), canal resinífero (CR). 
The needles' chemical components are presented in Table 1, and are in close agreement with the values observed for two-year-old Pinus strobus near Toronto, Canada (HODSON; SANGESTER, 2002). The ash content is low, showing the needles' good potential for energy production.

The extractive content of the needles was higher than that found for Pinus taeda wood in the work of Andrade (2006), with averages of 30\%. The needles have a high content of extractives, probably located in the resin channels, as well as a high lignin content, which causes the rigidity of the structure.

The main acids found in the extracts of loblolly pine needles are $\omega$-hydroxy hexadecanoic, $\omega$-hydroxy dodecanoic, and hydroxy tetradecanoic acids, all widely used in the formulation of skin cosmetic products, especially for the facial region, for the prevention and treatment of aging and blemishes. Due to the high content of extractives, the use of needles as a source of these components can be attractive. The chemical constituents of these needles can be used in cosmetics, but this requires a cost-benefit analysis to ascertain the cost of the chemicals involved in the extraction and the time required versus the amount and value of the extracted byproducts. This aspect will be the subject of future studies.

The characteristics of charred needles at different carbonization temperatures are shown in Table 2.

When comparing the untreated and charred needles after solvent extraction, there was a small increase in calorific value and fixed carbon content. Thus, this step does not alter the production of charcoal from the energy standpoint. With the removal of extractives before carbonization, there was an increase of $2.9 \%$ in the calorific value, $14.15 \%$ in ash content and no statistical difference in fixed carbon content of the charcoal produced at $500^{\circ} \mathrm{C}$.

There were statistically significant differences in the calorific values between the different carbonization processes except between temperatures of $600^{\circ} \mathrm{C}$ and 700 ${ }^{\circ} \mathrm{C}$. The highest calorific value for needle charcoal has been achieved with a final carbonization temperature of $600^{\circ} \mathrm{C}$. The fixed carbon content suggests the use of this material to make cooking briquettes. It should also be considered that the ash content is much lower than found in Brazilian briquette brands, which is around $25 \%$.

The calorific value of pine needles is higher than that of cotton seed husks $(11.70 \mathrm{MJ} / \mathrm{kg})$, corncobs (12.12 MJ / kg), babassu coconut husks (18.81 MJ / kg) (REDENERGIA, 2010), castor beans (18.84 KJ / Kg)
Table 1 - Chemical composition of Pinus sp. needles.

Tabela 1 - Composição química das acículas de Pinus sp.

\begin{tabular}{lll}
\hline Component & $\%$ & $\mathrm{CV}$ \\
\hline Cold water extractives & 17.90 & 1.31 \\
Hot water extractives & 20.71 & 1.38 \\
Ethanol-toluene extractives & 14.07 & 1.15 \\
Total extractives & 30.01 & 2.65 \\
Sodium hydroxide extractives & 47.02 & 0.97 \\
Ash & 2.32 & 1.20 \\
Lignin & 43.37 & 0.78 \\
\hline
\end{tabular}

Table 2 - Characteristics of Pinus sp. needles and charcoal produced.

Tabela 2 - Características das acículas de pinus e do carvão produzido.

\begin{tabular}{cccc}
\hline Material & $\begin{array}{c}\text { Ash } \\
(\%)\end{array}$ & $\begin{array}{c}\text { Calorific value } \\
(\mathrm{MJ} / \mathrm{Kg})\end{array}$ & $\begin{array}{c}\text { Fixed carbon } \\
\text { content }(\%)\end{array}$ \\
\hline $\begin{array}{c}\text { Needles } \\
\text { Needles carbonized at } \\
500^{\circ} \mathrm{C}\end{array}$ & $6.36 \mathrm{a}$ & $20.30 \mathrm{a}$ & $19.90 \mathrm{a}$ \\
$\begin{array}{c}\text { Extract from needles } \\
\text { carbonized at } 500^{\circ} \mathrm{C}\end{array}$ & $7.26 \mathrm{c}$ & $28.68 \mathrm{~b}$ & $66.36 \mathrm{~b}$ \\
$\begin{array}{c}\text { Needles carbonized at } \\
600^{\circ} \mathrm{C}\end{array}$ & $8.00 \mathrm{~d}$ & $29.64 \mathrm{~d}$ & $67.30 \mathrm{~b}$ \\
$\begin{array}{c}\text { Needles carbonized at } \\
700^{\circ} \mathrm{C}\end{array}$ & $8.86 \mathrm{e}$ & $29.41 \mathrm{~d}$ & $85.31 \mathrm{~d}$ \\
\hline
\end{tabular}

*Same letters in the column mean no significant difference by the Tukey test at $95 \%$ probability.

(DRUMMOND et al., 2006), eucalyptus (19.25 MJ / kg) (BRITO et al., 1983; PEREIRA et al., 2000), pine wood (20.03 MJ $/ \mathrm{kg}$ )(BRITOetal., 1984), ricehusks(12.92 MJ $/ \mathrm{kg}$ ) and carbonized rice husks (15.33 MJ / kg) (SOUZA et al., 2007). The calorific value of charred needles was similar to that of coconut charcoal (VALE et al., 2004).

The ash content of the untreated needles $(2.32 \%)$ was smaller than that of coconut husks (VALE et al., 2004), rice husks (SOUZA et al., 2007) and greater than that of eucalyptus wood (BRITO et al., 1983). The ash content of the needles charred at different temperatures was higher than that of pine wood (BRITO et al., 1984) and smaller than that found by Souza et al. (2007) for rice husk charcoal.

Cerne, Lavras, v. 20, n. 2, p. 245-250, abr.jun. 2014 
The fixed carbon content was smaller than that of coconut husks and $21.09 \%$ higher than that of rice husks. Needles charred at $700{ }^{\circ} \mathrm{C}$ had fixed carbon content higher than that found for coconut charcoal by Vale et al. (2004), of $75.10 \%$, and for rice husk charcoal found by Souza et al. (2007), of $45.65 \%$.

Under conditions similar to those used to obtain needle charcoals, the fixed carbon content was smaller compared to Eucalyptus sp. and Mimosa scabrela wood charcoal, but with an increase in the final carbonization temperature from $500{ }^{\circ} \mathrm{C}$ to $700{ }^{\circ} \mathrm{C}$, the fixed carbon content increased $28 \%$ in the carbonized needles.

The true density for the pine needle was found to be about $1.363 \mathrm{~g} / \mathrm{cm}^{3}$. The pine needle has a thick wall (Figure 1) with the presence of cuticle and densified structure to prevent loss of moisture to the outside and thus desiccation of the leaves (TAIZ; ZEIGER, 2004). This fact also reflects the high lignin content found (Table 1) for the needles.

According to Brito and Barrichello (1977), the best coals are produced with woods with high densities and better chemical properties (greater content of fixed carbon and lignin and lower levels of volatile substances and ashes). This feature is applicable to waste as well, where higher density and lignin content increase the quality and yield of the charcoal produced.

The presence of resin, as can be observed in Figure 1 through anatomy, also favors the increase in calorific value (Table 2) to the pine needle residue.

With increasing temperature, a noticeable decrease in the charcoal yield was observed (Table 3). This is due to further degradation of the chemical components of the needles, probably extractives and holocellulose.

The yield of liquor was affected by final carbonization temperature and solvent extraction prior to carbonization.

The charcoal yield was lower than that obtained by Souza et al. (2007) for rice husks (43.25\%) carbonized at $600{ }^{\circ} \mathrm{C}$, and higher than for Eucalyptus grandis wood (33.3\%) carbonized at $450{ }^{\circ} \mathrm{C}$ (BRITO et al., 1983).

The highest yield of pyroligneous liquor was obtained with carbonization temperature of $600{ }^{\circ} \mathrm{C}$, which coincides with the highest charcoal calorific value, showing that this is the right temperature for optimum process efficiency.

The oily part of the liquor can be used as fuel, so-called bio-oil. The liquor can also be distilled to separate a fraction useful in the food industry. Finally, pyroligneous liquor can be used to grow pine seedlings or other species, because it contains organic substances that can prevent the proliferation of organisms that attack plants. But further needle carbonization tests are required with this byproduct.

Table 3 - Gravimetric charcoal yield of Pinus sp. needles.

Tabela 3 - Rendimento gravimétrico do carvão das acículas de Pinus sp.

\begin{tabular}{lll}
\hline $\begin{array}{l}\text { Carbonization } \\
\text { Temperature }\end{array}$ & Charcoal yield (\%) & Liquor yield (\%) \\
\hline $500{ }^{\circ} \mathrm{C}$ & 63.03 & 39.43 \\
Extracted $500^{\circ} \mathrm{C}$ & 35.70 & 39.27 \\
$600^{\circ} \mathrm{C}$ & 28.48 & 45.05 \\
$700^{\circ} \mathrm{C}$ & 26.29 & 44.31 \\
\hline
\end{tabular}

\section{CONCLUSIONS}

Charcoal from pine needles has good energy potential due to the low ash content and a calorific value, which match those of the species that are commercially used as biomass.

The chemical extraction process before charring did not increase the calorific value, and considering the cost and time spent in the process, this is feasible only if the chemicals can be used for other value-added products.

The best temperature for the carbonization of pine needles is $600^{\circ} \mathrm{C}$, resulting in a higher yield of pyroligneous liquor and charcoal with the highest calorific value.

\section{AKNOWLEDGEMENTS}

We gratefully acknowledge the Brazilian agency CNPq for the research fellowship to WLEM and GIBM, which allowed this work to be realized.

\section{REFERENCES}

ANDRADE, A. S. de. Qualidade da madeira, celulose e papel em Pinus taeda L.: influência da idade e classe de produtividade. 2006. 94 p. Dissertação (Mestrado em Ciências Florestais) - Universidade Federal do Paraná, Curitiba, 2006.

\section{ASSOCIAÇÃO BRASILEIRA DE NORMAS}

TÉCNICAS. NBR 8112: carvão vegetal: análise imediata. Rio de Janeiro, 1983.

Cerne, Lavras, v. 20, n. 2, p. 245-250, abr./jun. 2014 


\section{ASSOCIAÇÃO BRASILEIRA DE NORMAS}

TÉCNICAS. NBR 8633: carvão vegetal: determinação do poder calorífico: método de ensaio. Rio de Janeiro, 1984.

BRITO, J. O.; BARRICHELO, L. E. G. Correlações entre características físicas e químicas da madeira e a produção de carvão vegetal: 1., densidade e teor de lignina da madeira de eucalipto. IPEF, Piracicaba, v. 14, p. 9-20, jul. 1977.

BRITO, J. O.; BARRICHELO, L. E. G.; SEIXAS, F. Análise da produção energética e de carvão vegetal de espécies de eucalipto. IPEF, Piracicaba, n. 23, p. 53-56, abr. 1983.

BRITO, J. O.; BARRICHELO, L. E. G.; SEIXAS, F. Estudo tecnológico da madeira de Pinus spp para a produção de carvão vegetal e briquetagem. IPEF, Piracicaba, n. 26, p. 25-30, abr. 1984.

CORTEZ, L. A. B.; LORA, E. E. S.; GOMES, E. O. Biomassa para energia. Campinas: UNICAMP, 2008.

COUTO, H. T.; BRITO, J. O. Inventário de resíduos florestais. IPEF, Piracicaba, v. 1, n. 2, p. A.1-A.13, jul. 1980.

DRUMMOND, A. R. F.; GAZINEU, M. H. P.; ALMEIDA, L.; SOUTO, M. A. Produção e valor energético da torta de mamona do agreste Pernambucano. In: CONGRESSO BRASILEIRO DE MAMONA, 2., 2006, Aracaju. Anais... Aracaju: EMBRAPA, 2006. 1 CD-ROM.

GARCÍA-ÁLVAREZ, C.; MORLA, J. S.; GARCIAAMORENA, I. Taxonomic differences between Pinus sylvestris and $P$. uncinata revealed in the stomata and cuticle characters for use in the study of fossil material.

Review of Palaeobotany and Palynology, Amsterdam, v. 155, n. 1/2, p. 61-68, May 2009.

HODSON, M. J.; SANGSTER, A. G. X-ray microanalytical of mineral localization in the needles of white pine (Pinus strobes L.). Annals of Botany, London, v. 89, n. 4, p. 367-374, 2002.

JOHANSEN, D. A. Plant microtechnique. London: McGrawHill, 1940. 523 p.

MANCILLA, F. S. G.; TOMAZELLO, M. F. Caracterização anatômica de acículas de espécies e

Cerne, Lavras, v. 20, n. 2, p. 245-250, abr./jun. 2014 variedades de Pinus. IPEF, Piracicaba, n. 28, p. 49-56, dez. 1984.

PEREIRA, J. C. D.; STURION, J. A.; HIGA, A. R.; HIGA, R. C. V.; SHIMIZU, J. Y. Características da madeira de algumas espécies de eucalipto plantadas no Brasil. Colombo: EMBRAPA Florestas, 2000. 113 p. (Documentos, 38).

REDENERGIA. Poderes caloríficos. Available at: $<$ http://redenergia.com.br/infotec.asp $>$. Access on: 11 Apr. 2010.

SOARES, T. S.; CARNEIRO, A. C. O.; GONÇALVES, E. O.; LELLES, J. G. Uso da biomassa florestal na geração de energia. Revista Científica Eletrônica de Engenharia Florestal, Garça, ano 4, n. 8, ago. 2006. Available at: <http:// www.agencia.cnptia.embrapa.br/Repositorio/ florestal1_000gapwcajw02wx5ok04xjloyxd3fpu2.pdf>. Access on: 1 Dec. 2010.

SOUZA, R. C. R.; SANTOS, E. C. S. dos; MORAIS, M. R.; SEYE, O. Carbonização da casca de arroz (Oriza sativa) para uso energético. In: CONGRESSO BRASILEIRO DE ENGENHARIA AGRÍCOLA, 36. 2007, Manaus. Anais... Available at: <http://cdeam. ufam.edu.br/artigos/resumo\%20expandido\%20arroz. pdf>. Access on: 1 Dec. 2010.

TAIZ, L.; ZEIGER, E. Fisiologia vegetal. 3. ed. Porto Alegre: Artmed, 2004. 719 p.

TECHNICAL ASSOCIATION OF PULP AND PAPER INDUSTRY. TAPPI testing and methods. Peachtree Corners, 1994.

THÖRNQVIST, T. Drying and storage of forest residues for energy production. Biomass, London, v. 7, n. 2, p. 125-134, 1985.

VALE, A. T.; BARROSO, R. A.; QUIRINO, W. J. Caracterização da biomassa e do carvão vegetal do cocoda-bahia (Cocos nucifera L.). Biomassa \& Energia, Rio de Janeiro, v. 1, n. 4, p. 365-370, 2004.

Received: September 28, 2011; accepted: November 04, 2013. 